\title{
First Miocene megafossil of arrowhead, alismataceous plant Sagittaria, from South America
}

Juan M. Robledo, Silvina A. Contreras, Johanna S. Baez, and Claudia I. Galli

Acta Palaeontologica Polonica 66 (3), 2021: s111-s122 doi:https://doi.org/10.4202/app.00835.2020

The first pre-Quaternary representative of Alismataceae from South America is reported based on achenes of Sagittaria

montevidensis from the Palo Pintado Formation (upper Miocene) in the south of Salta Province, Argentina. Achenes

are laterally compressed, have a lateral beak and a single recurved seed inside them. The fruits were found both in the

base (10 Ma) and the top of the formation ( 5 Ma), suggesting similar environmental conditions during this time period.

A cursory review of the Alismataceae family in the fossil record, with a special interest in those South American reports

is given. During the Oligocene-Miocene Sagittaria may have arrived from tropical Africa to South America and thence

to North America.

Key words: Alismataceae, Sagittaria, achene, aquatic plants, fossil fruits, Neogene, Argentina.

Juan M. Robledo [robledomanuel182@gmail.com] and Silvina A. Contreras [sailcontreras11@gmail.com], Laboratorio de Paleobotánica y Palinología desde el Neógeno hasta la Actualidad en el Norte de Argentina, Centro de Ecología Aplicada del Litoral (CONICET-UNNE), Ruta 5, km 2.5. W3400, Corrientes, Argentina and Facultad de Ciencias Exactas, Naturales y Agrimensura-Universidad Nacional del Nordeste. Av. Libertad 5450, W3400. Corrientes, Argentina. Johanna S. Baez [johannasbaez@gmail.com], Laboratorio de Xilotafofloras del Neopaleozoico y Triásico de Sudamérica y Neógeno del Noroeste Argentino, Centro de Ecología Aplicada del Litoral (CONICET-UNNE), Ruta 5, km 2.5. W3400. Corrientes, Argentina. Claudia I. Galli [cgalli@unsa.edu.ar], Instituto de Ecorregiones Andinas (INECOA-UNJu), Av. Bolivia 1661, S.S. de Jujuy, Universidad Nacional de Salta, Facultad de Ciencias Naturales. Av Bolivia 5150, Salta, Argentina. 
This is an open-access article distributed under the terms of the Creative Commons Attribution License (for details please see creativecommons.org), which permits unrestricted use, distribution, and reproduction in any medium, provided the original author and source are credited.

For Full text $(1,727.9 \mathrm{kB})$ 